AGRARIS: Journal of Agribusiness and Rural Development Research

Vol. 7 No. 2 July - December 2021 Pages: 160-175

Article history:

Submitted: April 26 $6^{\text {th }}, 2021$

Revised : August 23 $3^{\text {rd }}, 2021$

July $22^{\text {nd }}, 2021$

Accepted : August 24th, 2021
Garist Sekar Tanjung*, Any Suryantini, and Arini Wahyu Utami Department Agricultural Socioeconomic, Universitas Gadjah Mada, Indonesia

*) Correspondence email: gstsekar57@gmail.com

\title{
The Priorities of Leading Sub-Sector in The Sector of Agriculture, Forestry, and Fisheries in Economic Development in Bangka Belitung Province
}

\author{
DOI: https://doi.org/10.18196/agraris.v7i2.11615
}

\begin{abstract}
The aim of the study is to determine the priorities of the leading sub-sector in agriculture, forestry, and fisheries on economic development in The Province of Bangka Belitung Island. The descriptive-analytical method is used to describe and explain the dynamical performance of each sub-sector. The sub-sector performance is represented by GRDP of Bangka Belitung Province and GDP of Indonesia based on constant prices in 2010 for the 2010-2020 periods. Analysis of Klassen Typology, Location Quotient (LQ), and Dynamic Location Quotient (DLQ) are conducted to determine the sub-sector and its position among other sub-sectors. The analysis results show that the plantation crop is a leading subsector priority for the economic development in the Bangka Belitung Province.
\end{abstract}

Keywords: Agriculture, Bangka Belitung, GRDP, leading sub-sector

\section{INTRODUCTION}

Economic development is one of the national development goals in a country to encourage equitable distribution. This activity is closely related to implementing development at the regional level to achieve equitable development in all corners of the country. National development planning is a communication medium for national goals to external and internal stakeholders (Chimhowu, Hulme, \& Munro, 2019). Regional economic development strategies can be carried out by physical/local development, business; human resource; and many other strategies to develop the community's economy. Several indicators that can be used to measure the success of economic development are economic growth, per capita income, poverty rates, and others (Chisadza \& Bittencourt, 2019).

Economic growth is a process of increasing the production of goods and services in people's economic activities, which describes the development of an economy in one year compared to the previous year (Sjafrizal, 2016). Gross Regional Domestic Product (GRDP) can be used as an indicator of the economic growth performance of a region. A large 
percentage indicates the dependence on the production capacity of that sector. For example, agriculture, forestry, and fisheries are the leading sector and have a high contribution to the economy in the Province of Bangka Belitung Islands (Yulianti, 2019). The agricultural sector is the basic in Bangka Belitung Province (Monica, Mawra, \& Yulianita, 2017). This is supported by $\mathrm{Hu} \&$ Blakely (2013) research shows that the local economies of more remote and smaller communities are more dependent on some specialized industries, such as tourism and agriculture. This illustrates that the business sector in agriculture is an important sector that plays a role in the regional economy. Agriculture has a strong relationship with the business sector in other fields which positively affects the growth of regional output as a whole (Abidin, 2015). In developing the country's economic growth, there needs to be a push to increase growth in the agricultural sector, where the smart agriculture economic growth in 2020 will be at 96\% (Li \& Zheng, 2021).

With the existing potential, the Provincial Government of Bangka Belitung can take advantage of opportunities to increase the added value of agriculture which is reflected in regional development programs, strategic plans, and work plans of the fisheries, agriculture, and food offices in order to encourage economic growth and ensure food availability in an area (Ali et al., 2020; Marina et al., 2018). The policy that needs to be carried out by the government to achieve regional development goals is to prioritize regional development according to the potential possessed by each region so that the efforts made can be achieved optimally. The success of a region in carrying out its development is strongly influenced by the quality of planning based on the potential of its resources so that the region can manage existing resources to encourage economic growth as expected.

So each region needs to know the basic and non-basic sectors as well as sub-sectors and leading commodities in their economic structure so that the implementation of development can be more focused. Thus, the purpose of this study is to determine the relative position of each sub-sector in the context of accelerating GRDP growth in the agriculture, forestry, and fisheries sectors. In addition, this research was also carried out to improve previous research in analyzing the contribution and leading sub-sectors in the agriculture, forestry, and fisheries sectors in the Province of The Bangka Belitung Islands, where previous research was discussed the basic sector in all business in the Province of Bangka Belitung. However, this study is more specific to the agricultural sector in determining its superior sub-sector, so this research is more focused on discussing the determination of the agricultural sub-sector in Bangka Belitung Province.

\section{RESEARCH METHOD}

The data used in this study is secondary data in 2010-2020. The types and sources of data collected are from the yearbook of Indonesian statistics and Statistics of the Bangka Belitung Islands Province which include data on Gross Domestic Product (GDP) and Gross Regional Domestic Product (GRDP) at Constant Prices in 2010; and various other scientific journals. 


\section{Data Analysis}

Overlay Analysis

Determining the priority of the leading sectors is done by using the overlay analysis technique. Overlay analysis is a technique used to conclude by combining several analysis results (Kharisma \& Ferry, 2019). The results of the overlay analysis are used to determine the leading economic sub-sectors (Kuncoro, 2012). This technique uses the calculation of LQ, DLQ, and Typology Klassen (ri). The five priority indicator predictions from the results of the overlay analysis can be seen in Table 1.

\section{TABLE 1. THE PRIORITY INDICATOR CATEGORY}

\begin{tabular}{ccccc}
\hline No & LQ & DLQ & $\mathrm{I}_{\mathrm{i}}$ & Category \\
\hline 1 & + & + & + & Leading \\
2 & + & - & - & Mainstay \\
3 & - & + & + & Potential \\
4 & - & - & + & Developing \\
5 & - & - & - & Underdeveloped \\
\hline
\end{tabular}

Location Quotient (LQ)

Economic basis analysis often referred to as the economic basis theory, is usually used to identify GRDP in determining the base sector. According to Sjafrizal (2018), it is explained that the LQ technique can divide the economic activities of an area into two groups, namely: 1) Basic industries, namely economic or industrial activities that serve the regional market itself or outside the region concerned, and 2) Non-basic industries, namely economic or industrial activities that only serve the local market.

Location Quotient (LQ) analysis can show the magnitude of the contribution of the economic sector of the Bangka Belitung Islands Province in terms of contribution by comparing the contribution of the same sector nationally. This analysis uses the GRDP value approach with the formula:

$L Q=\frac{E_{i j} / E_{j}}{E_{\text {in }} / E_{n}}$

Note :

LQ : Location Quotient Coefficient (LQ)

$\mathrm{E}_{\mathrm{ij}} \quad$ : GRDP of sub-sector i in Bangka Belitung Province

$\mathrm{E}_{\mathrm{j}} \quad$ : Total of GRDP in Bangka Belitung Province

$\mathrm{E}_{\text {in }} \quad$ : GDP of sub-sector $\mathrm{i}$ at national level

$\mathrm{E}_{\mathrm{n}} \quad$ : Total of GDP at national level

Criteria of the Measurement:

a. If the value of $L Q \geq 1$, Sub-sector whose level of specialization is higher than the reference level

b. If the value of $L Q<1$, Sub-sector whose level of specialization is lower than the reference level.

Furthermore, Dynamic Location Quotient (DLQ) analysis was used to determine whether a sub-sector has the potential to become a leading sub-sector in the future with the following formula (Widodo, 2006). 
$D L Q=\left[\frac{\left(\frac{1+g i j}{1+g j}\right)}{\left(\frac{1+G i}{1+G}\right)}\right]^{t}$

Note:

DLQ : Index Dynamic Location Quotient

$\mathrm{g}_{\mathrm{ij}} \quad$ : The growth rate of sub-sector i in Bangka Belitung Province

$\mathrm{g}_{\mathrm{j}} \quad$ : The average sub-sector growth rate in Bangka Belitung Province

$\mathrm{G}_{\mathrm{i}} \quad$ : The growth rate of sub-sector $\mathrm{i}$ at the national level

G : The average growth rate of the sub-sectors at the national level

$\mathrm{t} \quad$ : Time of analysis

Criteria of the Measurement:

a. If DLQ $\geq 1$, The growth rate of sub-sector $\mathrm{i}$ in Bangka Belitung Province is higher than the growth rate of the sub-sector at the national level

b. If DLQ $<1$, The growth rate of sub-sector $\mathrm{i}$ in Bangka Belitung Province is lower than the growth rate of the sub-sector at the national level.

The combination of LQ and DLQ values is used to determine whether the economic sub-sector is classified as Dominant, Prospective, Mainstay, and Underdeveloped using Table 2 (Kuncoro, 2012).

\section{TABLE 2. CLASSIFICATION OF SUB-SECTORS BASED ON THE COMBINATION OF LQ AND DLQ}

\begin{tabular}{ccc}
\hline Nilai & $L Q>1$ & $D L Q<1$ \\
\hline$D L Q>1$ & Dominant & Mainstay \\
$D L Q<1$ & Prospective & Underdeveloped \\
\hline
\end{tabular}

Sources: Kuncoro (2012)

Klassen Typological Analysis

Klassen's typological analysis is used to identify the position of the agriculture, forestry and agriculture sub-sector in the Province of the Bangka Belitung Islands by taking into account the economic sub-sector in the national region as a reference area. The output of this analysis is expected to determine the position and structure of the economic sector of Bangka Belitung Province which can be used as a supporting reference to determine priorities in the development of the agricultural sub-sector development. According to Sjafrizal (2016), there are four classifications with different characteristics between subsectors, namely :

a) Quadrant I: Mainstay Sector is a sector in the quadrant where the GRDP growth rate of certain sectors in Bangka Belitung Province has an average growth rate above the National GRDP growth and has a sector contribution value to GRDP that is greater than GRDP growth National. Sector contribution at the national level ( $r i>r$ and $y i>y$ ).

b) Quadrant II: Potential Sector is a sector that is in the quadrant where the GRDP growth rate of certain sectors in Bangka Belitung Province has an average growth rate that is smaller than the growth of national GDP but has a contribution value that is greater than its contribution. Sector at the national level ( $\mathrm{ri}<\mathrm{r}$ and $\mathrm{yi}>\mathrm{y}$ ).

c) Quadrant III: Developing Sector, is a sector that is in the quadrant where the GRDP growth rate of certain sectors in Bangka Belitung Province has an average growth rate 
above the national GRDP growth but has a contribution value than the national level (ri $>\mathrm{r}$ and $\mathrm{yi}<\mathrm{y}$ ).

d) Quadrant IV: Relatively Underdeveloped Sector, is a sector in the quadrant where the GRDP growth rate of certain sectors in Bangka Belitung Province has a growth rate and contribution value that is smaller than the growth rate and contribution of the same sector at the national level ( $\mathrm{ri}<\mathrm{r}$ and $\mathrm{yi}<\mathrm{y}$ ). The classification of each group can be seen in Table 3.

TABLE 3. KLASSEN TYPOLOGY CLASSIFICATION

\begin{tabular}{|c|c|c|}
\hline Growth (r) Contribution (y) & $y_{i}>y$ & $y_{i}<y$ \\
\hline \multirow{2}{*}{$r_{i}>r$} & Quadrant I & Quadrant II \\
\hline & $\overline{\text { Dominant }}$ & Potential \\
\hline \multirow{2}{*}{$r_{i}<r$} & Quadrant III & Quadrant IV \\
\hline & Developing & Underdeveloped \\
\hline
\end{tabular}

Source: Sjafrizal (2016)

Note:

$\mathrm{r}_{\mathrm{i}} \quad$ : growth rate of sub-sector $\mathrm{i}$ in Bangka Belitung Province

r : growth rate of the GDP agriculture sub-sector at the national level

$y_{i} \quad$ : contribution of sub-sector i in Bangka Belitung Province

y : contribution of the GDP agriculture sub-sector at the national level

\section{RESULTS AND DISCUSSION}

Concentration and Potential of the Agriculture, Forestry, and Fisheries Sub-sectors in Bangka Belitung Islands Province

The Location Quotient (LQ) and Dynamic Location Quotient (DLQ) methods are one of the most well-known analysis techniques of the economic base model to determine the basis or non-base sectors. The results showed that the Agricultural Sub-sector which has a superior sub-sector classification, is only in the Plantation Sub-sector with an LQ calculation of 1.52 and DLQ of 1.07. This shows that the plantation sub-sector has basic values, both now and in the future. Plantation commodities that provide the largest contribution to the economy of Bangka Belitung Province are oil palm (147.330.45 tons); rubber (56,629.01 tons); and pepper (33,457.64 tons) (Statistics of Kepulauan Bangka Belitung Province, 2021). The subsector that has these basic values can be a driving force in encouraging economic growth in the Bangka Belitung Province. Not only meeting the needs of regencies/cities in their area, the sub-sector is also able to meet from outside the region (Darma Putra \& Yuli Pratiwi, 2019).

The fisheries sub-sector shows an LQ value of more than one (1.99) which indicates that this sub-sector is a basic sub-sector in Bangka Belitung Province. This is supported by the geographical factors of Belitung Regency as an archipelagic country, so that fishery production is abundant and can be exported outside the region (Yulianti, 2019). This research is in line with Ibrahim (2018) research which states that the Fisheries Sub-sector is able to absorb a very high workforce. However, the DLQ value in the fisheries sub-sector in 
this region is $<1$; this indicates that this sub-sector does not have a baseline value in the future period. Meanwhile, the food crops sub-sector; and forestry shows the results of the LQ analysis < 1, so it is not a basic sector in the current period, but the DLQ value shows that the food crops sub-sector (1.40); and the forestry and logging sub-sector (1.13) has a baseline. It shows that the sub-sector is included in the classification of the mainstay sector, so it still has the potential to be repositioned as a basic sector in the future. The analysis results were different from the horticultural crop sub-sector, farmland, and agricultural and hunting services, which show LQ and DLQ values $<1$, so they are included in the category of relatively lagging sub-sectors. Table 4 is the results of the calculation of the LQ and DLQ methods using GRDP and data of GRDP for the Bangka Belitung Province in the 20102020 period. It was present to make the discussion easier to understand.

TABLE 4. AVERAGE LQ AND DLQ OF AGRICULTURE SUB-SECTOR IN BELITUNG REGENCY 2010-2020

\begin{tabular}{llllll}
\hline \multirow{2}{*}{ Sub-sector } & \multicolumn{3}{c}{ Average } & \multirow{2}{*}{ Conclusion } \\
\cline { 2 - 5 } & \multicolumn{2}{c}{ LQ } & DLQ & \\
\hline Food Crops & 0.12 & - & 1.40 & + & Mainstay \\
Horticultural Crops & 0.96 & - & 0.84 & - & Underdeveloped \\
Plantation crops & 1.52 & + & 1.07 & + & Dominant \\
Livestock & 0.44 & - & 0.99 & - & Underdeveloped \\
Agriculture Service and Hunting & 0.78 & - & 0.96 & - & Underdeveloped \\
Forestry/and Logging & 0.34 & - & 1.13 & + & Mainstay \\
Fishery & 1.99 & + & 0.83 & - & Prospective \\
\hline
\end{tabular}

Sources: Statistics of Kepulauan Bangka Belitung Province, (2020)

Sub-sectors that have non-basic values should support the basic sector but still need to be strengthened again so that economic growth and the community's economy can increase. Efforts and strategies are needed so that this sub-sector can have basic values in the future so that later it is hoped that these sub-sectors can become a leading sector that can be a driving force for other sectors to grow into the driver of regional. Meanwhile, the basic sub-sector that drives the economy in the Bangka Belitung Province needs to be further improved by providing convenience in business licensing, increasing investment, holding various training, and providing investment to the community (Satrianto \& Sasongko, 2019).

Structure and Position of the Agriculture, Forestry, and Fisheries Sub-sectors in the Province of the Bangka Belitung Islands

Klassen Typology is used to classify each sub-sector in the agriculture, forestry, and fisheries Sector in Bangka Belitung Province based on its growth structure. Local governments can use this analysis as a base decision-maker to determine priorities for regional revenue and expenditure budgets, especially those related to the expenditure side, to focus more on the sector, sub-sector, business, and commodity development (Listya, Ferrianta, \& Makki, 2018). Based on the type of business field, each sub-sector during the 2010-2020 periods shows a different position. This approach compares each sub sector's average growth and contribution with the same economic activity at the national level. Table 5 shows the analysis results. 
TABLE 5. THE AVERAGE GROWTH AND CONTRIBUTION OF THE AGRICULTURAL, FORESTRY, AND FISHERIES SUB-SECTORS IN BANGKA BELITUNG REGENCY AND NATIONAL INDONESIA

\begin{tabular}{lccccccccc}
\hline \multirow{2}{*}{ Sub-sector } & \multicolumn{4}{c}{ Growth $(\mathrm{r})$} & \multicolumn{4}{c}{ Contribution $(\mathrm{y})$} \\
\cline { 2 - 10 } & $\left(\mathrm{r}_{\mathrm{i}}\right)$ & $(\mathrm{r})$ & $(\mathrm{r}) \mathrm{r})$ & $\left(\mathrm{y}_{\mathrm{i}}\right)$ & $(\mathrm{y})$ & \multicolumn{2}{c}{$\left(\mathrm{y}_{\mathrm{i}} \mathrm{y}\right)$} \\
\hline Food Crops & 75,6 & 19,7 & $>$ & + & 3,2 & 23,8 & $<$ & - \\
Horticultural Crops & 37,5 & 44,5 & $<$ & - & 10,8 & 11,6 & $<$ & - \\
Plantation Crops & 92,0 & 53,1 & $>$ & + & 43,7 & 29,1 & $>$ & + \\
Livestock & 70,2 & 54,1 & $>$ & + & 5,1 & 11,8 & $<$ & - \\
Agriculture Service and Hunting & 65,3 & 44,6 & $>$ & + & 1,1 & 1,5 & $<$ & - \\
Forestry/and Logging & 45,6 & 8,7 & $>$ & + & 1,7 & 5,2 & $<$ & - \\
Fishery & 71,6 & 77,0 & $<$ & - & 34,3 & 17,0 & $>$ & + \\
\hline
\end{tabular}

Sources: Statistics of Kepulauan Bangka Belitung Province (2020)

Table 4 shows the average value of the agricultural growth, forestry, and fisheries subsectors from the largest to the smallest values. Respectively, which are plantation crops (92.0); food plants (75.6); livestock (70.2); agricultural and hunting services (65.3); and forestry / and logging (45.6). Two sub-sectors have lower average growth rates at the provincial level when compared to the national average, namely fisheries sub-sector (71.6) and horticultural crops (37.5).

Meanwhile, judging from the value of its contribution, Bangka Belitung Province shows a smaller contribution value of the sub-sector. Only the plantation subsector (43.7); and fisheries (34.3) which have a higher average contribution value at the provincial level than at the national level. The contribution value to the fisheries sub-sector is inversely proportional to the value of its growth, where this sub-sector has a greater contribution to the regional economy, but its growth is still relatively smaller than the overall national growth. The results of the analysis can be grouped into four quadrants, as shown in Figure 1.

\begin{tabular}{|c|c|}
\hline $\begin{array}{c}\text { Quadrant I } \\
\text { Dominant } \\
\text { Sub-sector } \\
\text { Plantation crops }\end{array}$ & $\begin{array}{c}\text { Quadrant II } \\
\text { Potential } \\
\text { Sub-sector } \\
\text { Food Crops } \\
\text { Livestock } \\
\text { Agriculture Service and Hunting } \\
\text { Forestry and Logging }\end{array}$ \\
\hline $\begin{array}{l}\text { Quadrant III } \\
\text { Developing } \\
\text { Sub-sector } \\
\text { Fishery }\end{array}$ & $\begin{array}{l}\text { Quadrant IV } \\
\text { Underdeveloped } \\
\text { Sub-sector } \\
\text { Horticultural Crops }\end{array}$ \\
\hline
\end{tabular}

FIGURE 1. THE GRDP SUB-SECTOR CLASSIFICATION OF BANGKA BELITUNG PROVINCE IS BASED ON KLASSEN TYPOLOGY

The dominant sub-sectors indicated by quadrant 1 is the one that experienced growth and contribution that was higher than the average for the same sub-sector at the national level. This sector is the most developed in the Bangka Belitung Province and is expected to grow rapidly in the future. The calculation results show that plantation crops are the dominant sector in Bangka Belitung Province. Meanwhile, the potential sub-sector in quadrant 2 is a sector with relatively large development potential but has not been fully 
managed optimally. This sector has a great opportunity to become a sector that continues to grow in the future. The sub-sectors included in this category are the food crops sub-sector, cattle; agricultural and hunting services; and the forestry and logging sub-sectors.

Quadrants III and IV are classified as developing and relatively lagging sub-sectors, where the developing sector is a relatively advanced sub-sector, but in recent years the growth rate has decreased. The sub-sector included in this category is the fisheries sub-sector. Meanwhile, the sub-sector that is relatively lagging behind is the sector that has a growth rate and contribution below the average of the same sector at the national level, namely the horticulture sub-sector.

In this grouping, it can be seen that in general, the economic sector in the Bangka Belitung Province is classified as a potential sector, but there are still sub-sectors belonging to quadrants III and IV, which indicate that regional policies have not been fully capable of having a significant accelerating effect on productivity growth in the sector. Agriculture as a whole, although in general, the agricultural sector has quite potential (Abidin, 2015). It shows that the growth rate and contribution of the agricultural sector are generally quite good. However, is a need for local government policies to change the position of the agricultural sub-sector which is still developing and relatively lagging behind. According to Sjafrizal (2016), if increasing activities in the economic growth are the main target of regional development, then increasing activities in the economic sector included in quadrants I and II must be prioritized. However, if equitable development is the main goal of the regional government, the development must be given to sectors that are included in quadrant III or IV.

One strategy to develop the fisheries sub-sector and horticultural crop sub-sector is to develop agro-tourism activities with an agro-industrial approach (Pambudi, Sunarto, \& Setyono, 2018). According to (Barkauskas, Barkauskienè, \& Jasinskas, 2015), when rural agrotourism has developed, it will affect local GRDP. Efforts to develop agro-industrial activities in this area are expected to be a trigger for the community to work on this subsector because of the certainty of the market that will receive the results (harvest) from the sub-sector. It is also expected to involve other sectors and have an impact on these economic sectors. One of the strategies to encourage agro-industry of the fishery sector in this province can be done with a development to the home industry in processed "seafood". In its marketing strategy, it is necessary to increase food diversity, food fortification, and supplementation with certain packaging designs (Nurliza, Suharyani, \& Nugraha, 2021). The home industry will develop community creativity in managing agricultural products into finished products. However, according to (Budi, Bhayangkara, \& Fadah, 2016), there are basic problems faced by small and home industries, including relatively short product durability; the limited use of technology, such as social media and websites as promotional media, is not given much attention; and the low quality of human resources is also an obstacle in doing business. Intensive technology development can be made a top priority in developing agro-industry (Timisela, Masyhuri, \& Darwanto, 2021), especially the use of technology in the home industry (Man, Wang, Zuo, \& Lin, 2020; Saleh \& Hubeis, 2018). 
Ranking of Leading Sub-sectors in the Agriculture, Forestry, and Fisheries in the Province of Bangka Belitung

The results of the typology analysis of LQ, DLQ, and Klassen are given criteria to obtain a description of the leading sub-sectors in the province of Bangka Belitung. Table 6 shows the ranking of development priorities for each sub-sector. From these calculations, it can be determined the priority scale in economic development planning in Bangka Belitung Province by classifying the conclusions into five groups, namely leading sub-sectors; potency; mainstay; develop; and go with the following discussion.

TABLE 6. ANALYSIS OF BANGKA BELITUNG PROVINCE ECONOMIC LEADING SUB-SECTOR OVERLAY 2010-2020

\begin{tabular}{lcccl}
\hline \multicolumn{1}{c}{ Sub-sector } & LQ & DLQ & $\mathrm{I}_{\mathrm{i}}$ & Category \\
\hline Food Crops & - & + & + & Potential \\
Horticultural Crops & - & - & - & Underdeveloped \\
Plantation Crops & + & + & + & Leading \\
Livestock & - & - & + & Developing \\
Agriculture Service and Hunting & - & - & + & Developing \\
Forestry/and Logging & - & + & + & Potential \\
Fishery & + & - & - & Mainstay \\
\hline Sources: Statistics of Kepulauan Bangka Belitung Province, (2020)
\end{tabular}

\section{Leading Sub-sector}

The sub-sector with the highest development priority ranking is the plantation subsector, the leading sector in Bangka Belitung Province. The results of this study are in accordance with the statement from the Statistics of Bangka Belitung Province, which states that the Plantation Crops Sub-sector is the largest contributor to the GRDP value of the agricultural sector in the region (Statistics of Kepulauan Bangka Belitung Province, 2020).

The most widely cultivated commodities in Bangka Belitung Province are oil palm, pepper, and rubber plants. Rubber production continues to increase in line with the plan to develop 40,000 hectares of rubber land, but currently, the land used for rubber commodities is only $\pm 12,000$ hectares (Statistics of Kepulauan Bangka Belitung Province, 2020). Meanwhile, in pepper plants, this commodity is one of the leading commodities which is widely known in the world because it has a distinctive taste and aroma. The use of certain enzymes in processing technology can improve the quality of pepper produced efficiently (Siswanto, Ardana, \& Karmawati, 2021). A popular type of pepper is white pepper with the name 'Muntok White Pepper'. This is because Bangka Belitung Province is the first production center of the pepper development area in Indonesia and has been the largest producer in the world since 2014 (Mahdi \& Suprehatin, 2021). South Bangka Region is the largest Pepper Producing Regency with the highest total production compared to other districts/cities in Bangka Belitung Province. However, it turns out that pepper farmers in this area still have a weak bargaining position in making decisions to determine the selling price of white pepper, so that farmers have to sell their harvests collectively (Purwasih, Pranoto, \& Atmaja, 2020). 
The primary plantation sub-sector also contributes value-added of IDR 61.1 trillion or 3.1 percent of the national GDP and has employed 13.4 million people, so this business field is very suitable to be used as a leading sub-sector to increase the GRDP of the agricultural sector in general (Susila \& Setiawan, 2016). The strengths of the plantation sector include high community motivation in looking for commodities in the plantation sub-sector, the availability of a large area of land, and the geographical and biophysical conditions of the land that are suitable for development plantation commodities. This can be an opportunity for the provincial government to turn this sub-sector into a leading sector (Hendris \& Jani, 2016). So, the strategies that the government can take to encourage the development of this sub-sector are: increasing the amount of production, added value, and competitiveness of plantation products through efforts to develop agribusiness systems; improving the understanding of human resources in understanding the potential of the export market with various training; providing information and promotion facilities from various media and other agribusiness exhibition activities, as well as expanding the network of partnerships and cooperation with the private sector and other parties in order to attract more investors (Helmi, Sriartha, \& Sarmita, 2021).

\section{Mainstay Sub-sector}

The fisheries sub-sector is a mainstay sub-sector and can continue to be developed in Bangka Belitung Province because of the area's characteristics, which is a coastal area and is very strategic and has the potential for abundant fisheries and marine resources. Marine fishery production in the Province of the Bangka Belitung Islands is generally concentrated on Belitung Island rather than on Bangka Island. Therefore, the development of fisheries investment can be carried out on Belitung Island specifically without ignoring Bangka Island by considering the amount of input used (Mardyani \& Yulianti, 2020).

The large potential of the fisheries sector is expected to create an increase in output, income, and job creation. The expansion of cultivation to various regions can play an important role in the development of this sub-sector (Wang \& Wang, 2021). In addition, other potentials that can be developed from the fisheries sub-sector are developing Marine Recreation Fisheries (MRF), which have a large socio-economic contribution for coastal communities but still need to pay attention to environmental regulations (especially fisheries) and marine spatial planning (Williams, Davies, Clark, Muench, \& Hyder, 2020). According to (Kharisma \& Ferry, 2019), policy implementation can be carried out by accelerating infrastructure to support fisheries and marine connectivity and development, as well as developing fishery sector-based areas that need to be focused on locations that are centers of economic growth to provide a large multiplier effect (Anggraeni, Rustiadi, \& Yulianto, 2020).

\section{Potential Sub-sector}

This sub-sector has a relatively large development potential but has not been managed optimally, including the food crops sub-sector, forestry, and logging. This sub-sector has the potential 
to become a leading sub-sector that can continue to be developed in the future. For example, the forestry sub-sector, according to national and international views, shows that the forestry and wood products sector has the potential to grow significantly in the future. (Nambiar, 2021). The existence of cheap and abundant forest resources and available labor should be two positive factors for economic development (Williams \& Kinard, 2003).

In addition, by taking advantage of the increase in the tourism sector in several areas in Bangka Belitung Province, it can be used as a driving factor in efforts to develop the agricultural subsector, especially in the potential sub-sector so that it can be developed further. Local governments are expected to facilitate agricultural products to be advertised, promoted, and used in various accommodations and restaurants around visitor tourist destinations (Cahyadi, Sasongko, \& Saputra, 2018). Some things that can be done, for example: strengthening agricultural organizations/institutions, improving the quality of human resources, and procuring other supporting facilities is also can be used as programs that can be developed in the development of the agricultural sector ( Rozaki, Wijaya, \& Wardana, 2021). According to Adenle et al., (2019), technological development in agriculture is also very much needed to support local food production. However, on average, Indonesian farmers, especially farmers in the food crop sub-sector, are usually elderly farmers, so the use of new technology or innovations is difficult to adopt in their agricultural activities (Rozaki, 2020).

According to Matchaya (2020), policymakers must be able to increase and optimally manage public expenditure budgets in the agricultural sector but must continue to emphasize increasing intra-sectorial allocations, as well as targeting dominant areas to create sectorial growth in order to increase productivity and professionalism in managing potential sectors. Government interventions to improve efficiency and productivity can be targeted at districts that still have low levels of efficiency and growth (Ahmad, Shankar, Steen, Verreynne, \& Burki, 2021).

\section{Developing and Underdeveloped Sub-sectors}

This study shows the same results as research of Listya et al., (2018) that horticultural crops are included in the lagging sub-sector category while developing sub-sectors include: livestock sub-sector; and agricultural services sub-sector, and hunting. If examined more deeply, livestock has a very important role in the economic and socio-cultural welfare of people in rural areas, for example as a source of income, creating employment in the livestock sector, increasing soil fertility, agricultural attractiveness, supply food, diversifying agriculture, and sustainable agricultural production. (Bettencourt, Tilman, Narciso, da Silva Carvalho, \& de Sousa Henriques, 2015). The low interest of the community in conducting livestock, horticulture, and agricultural services is one of the factors that cause these subsectors to be included in the category of developing and lagging sub-sectors.

There needs to be an effort by the local government to shift the position of this subsector into a leading or mainstay sector with various strategies that can be carried out. For example, the provision of guidance in each region based on existing potential and increasing various training, especially for young breeders (Pérez, Sendra, \& Gelats, 2020), as well as increasing the efficiency of the livestock sector through sustainable intensification practices (Herrero et al., 2013). Basically, competitive advantage and agricultural potential in an area can affect the growth of the general agricultural sector. However, efforts are still needed to 
utilize and develop the potential of the sector in order to encourage more optimal regional economic growth (Katti, Pratiwi, \& Setiahadi, 2019).

\section{CONCLUSION}

The growth of all agricultural sub-sectors in Bangka Belitung Province is faster than the same sub-sectors at the national level, but only the horticulture and fisheries sub-sectors have smaller growth than the national level. The plantation sub-sector is a basic sub-sector in the present and in the future, so it is a leading sub-sector that can be prioritized as an economic driver in Bangka Belitung Province. Policymakers must be able to formulate a scale of development priorities based on regional economic needs and objectives. If the main objective of regional development in Bangka Belitung Province is to focus on increasing economic growth, then development priorities must be directed at the plantation sub-sector as a leading sub-sector, for example by increasing the amount of production, added value, and competitiveness of plantation products through efforts to develop an agribusiness system from upstream, downstream and other related agencies; improve the understanding of human resources in understanding the potential of the export market with various training; providing information and promotion facilities from various media and other agribusiness exhibition activities, as well as expanding the network of partnerships and cooperation with the private sector to attract more investors. However, if equitable development is the main goal of the Bangka Belitung Provincial government, then development priority should be given to sectors that include developing and underdeveloped sub-sectors, namely the horticultural crops; Cattle; Agricultural Services and Hunting.

\section{REFERENCES}

Abidin, Z. (2015). An Application of the Shift Share Analysis for Transformation of the Agricultural Sector in Economic Areas at South East Sulawesi. Jurnal Informatika Pertanian, 24(2), 165-178.

Adenle, A. A., Wedig, K., \& Azadi, H. (2019). Sustainable agriculture and food security in Africa: The Role of Innovative Technologies and International Organizations. Technology in Society, 58(May), 101143. https://doi.org/10.1016/j.techsoc.2019.05.007

Ahmad, S., Shankar, S., Steen, J., Verreynne, M. L., \& Burki, A. A. (2021). Using Measures of Efficiency for Regionally-Targeted Smallholder Policy Intervention: The Case of Pakistan's Horticulture Sector. Land Use Policy, 101(May 2019), 105179. https://doi.org/10.1016/j.landusepol.2020.105179

Ali, Q., Raza, A., Narjis, S., Saeed, S., \& Khan, M. T. I. (2020). Potential of Renewable Energy, Agriculture, and Financial Sector for The Economic Growth: Evidence from Politically Free, Partly Free and Not Free Countries. Renewable Energy, 162, 934-947. https://doi.org/https://doi.org/10.1016/j.renene.2020.08.055 
Anggraeni, M., Rustiadi, E., \& Yulianto, G. (2020). Role of Fisheries Sector to Economy of the Natuna Regency. Jurnal Kebijakan Sosial Ekonomi Kelautan Dan Perikanan, 10(1), 11. https://doi.org/10.15578/jksekp.v10i1.8155

Barkauskas, V., Barkauskienè, K., \& Jasinskas, E. (2015). Analysis of Macro Environmental Factors Influencing the Development of Rural Tourism: Lithuanian Case. Procedia Social and Behavioral Sciences, 213, 167-172. https://doi.org/10.1016/j.sbspro.2015.11.421

Bettencourt, E. M. V., Tilman, M., Narciso, V., da Silva Carvalho, M. L., \& de Sousa Henriques, P. D. (2015). The Livestock Roles in The Wellbeing of Rural Communities of Timor-Leste. Revista de Economia e Sociologia Rural, 53, S063-S080. https://doi.org/10.1590/1234-56781806-94790053s01005

Budi, I., Bhayangkara, W. D., \& Fadah, I. (2016). Identification of Problems and Strategies of the Home-Based Industry in Jember Regency. Agriculture and Agricultural Science Procedia, 9, 363-370. https://doi.org/10.1016/j.aaspro.2016.02.151

Cahyadi, N. M. A. K., Sasongko, S., \& Saputra, P. M. A. (2018). Inclusive Growth and Leading Sector in Bali. Economic Journal of Emerging Markets, 10(1), 99-110. https://doi.org/10.20885/ejem.vol10.iss1.art11

Chimhowu, A. O., Hulme, D., \& Munro, L. T. (2019). The 'New' National Development Planning and Global Development Goals: Processes and Partnerships. World Development, 120, 76-89. https://doi.org/10.1016/j.worlddev.2019.03.013

Chisadza, C., \& Bittencourt, M. (2019). Economic Development and Democracy: The Modernization Hypothesis in Sub-Saharan Africa. Social Science Journal, 56(2), $243-$ 254. https://doi.org/10.1016/j.soscij.2018.10.007

Darma Putra, E., \& Yuli Pratiwi, M. C. (2019). Identification of Leading Sector and Cluster Analysis of Regencies in Kalimantan. Economics Development Analysis Journal, 8(2), 224243. https://doi.org/10.15294/edaj.v8i2.27237

Helmi, M., Sriartha, I. P., \& Sarmita, I. M. (2021). Strategi Pengembangan Komoditas Unggulan Subsektor Tanaman Perkebunan di Kabupaten Buleleng. Jurnal Jurusan Pendidikan Geografi, 9(1), 26-35.

Hendris, \& Jani, J. (2016). Role and Plantation Development Strategy Toward Regional Establishment of Malinau Regency. Agritrop Jurnal Ilmu-Ilmu Pertanian, 3(2), 231-238.

Herrero, M., Grace, D., Njuki, J., Johnson, N., Enahoro, D., Silvestri, S., \& Rufino, M. C. (2013). The Roles of Livestock in Developing Countries. Animal, 7(SUPPL.1), 3-18. https://doi.org/10.1017/S1751731112001954

Hu, R., \& Blakely, E. J. (2013). Measuring Tourism as The Economic Driver of Australian Sea Change Communities. Community Development, 44(3), 323-335. https://doi.org/10.1080/15575330.2013.794851

Ibrahim, I. (2018). Leading Sector and Absorption of Labor. Gorontalo Development Review, $1(2), 1-12$. 
Katti, S., Pratiwi, D., \& Setiahadi, R. (2019). Klassen Typology Approach for Analysis of the Role of Competitiveness Agricultural Sector. IOP Conference Series: Earth and Environmental Science, 347. https://doi.org/10.1088/1755-1315/347/1/012106

Kharisma, B., \& Ferry, H. (2019). Analysis of Potential Sectors and Policy Priorities of Regional Economic Development in Maluku. Etikonomi, 18(01), 29-46.

Kuncoro, M. (2012). Perencanaan Daerah: Bagaimana Membangun Ekonomi Lokal, Kota dan Kawasan. Jakarta: Salemba Empat.

Li, Y., \& Zheng, Y. (2021). Regional Agricultural Industry Economic Development Based on Embedded System and Internet of Things. Microprocessors and Microsystems, 82. https://doi.org/https://doi.org/10.1016/j.micpro.2021.103852

Listya, M. R., Ferrianta, Y., \& Makki, M. F. (2018). Analysis Typology of Agricultural Subsector Economic Growth in Banjar Regency , South Kalimantan Province , Indonesia. Journal of Agriculture and Veterinary Science, 11(9), 78-81. https://doi.org/10.9790/2380-1109027881

Mahdi, N. N., \& Suprehatin, S. (2021). Market's Position of Indonesian Pepper in The Global Market. Jurnal Ekonomi Pertanian Dan Agribisnis, 5(2), 595-605.

Man, X., Wang, Z., Zuo, Y., \& Lin, Z. (2020). The Vision of Design-Driven Innovation in China's Smart Home Industry. In Communications in Computer and Information Science. Springer Singapore. https://doi.org/10.1007/978-981-15-6113-9_6

Mardyani, Y., \& Yulianti, A. (2020). Analisis Pengaruh Sub Sektor Perikanan Terhadap Pertumbuhan Ekonomi Di Provinsi Kepulauan Bangka Belitung. Equity: Jurnal Ekonomi, 8(2), 41-50. https://doi.org/10.33019/equity.v8i2.47

Marina, M., Darwanto, D. H., \& Masyhuri, M. (2018). The Study of Leading Subsector and Leading Commodities of Agricultural in Anambas Islands Regency, Riau Islands Province. Agro Ekonomi, 29(1), 49. https://doi.org/10.22146/ae.30739

Matchaya, G. C. (2020). Public Spending on Agriculture in Southern Africa: Sectoral and Intra-sectoral Impact and Policy Implications. Journal of Policy Modeling, 42, 12281247. https://doi.org/https://doi.org/10.1016/j.jpolmod.2020.05.002

Monica, C. A., Mawra, T., \& Yulianita, A. (2017). Analisis Potensi Daerah Sebagai Upaya Meningkatkan Perekonomian Daerah di Sumatera Bagian Selatan. Jurnal Ekonomi Pembangunan, 15(1).

Nambiar, E. K. S. (2021). Strengthening Vietnam's Forestry Sectors and Rural Development: Higher Productivity, Value, and Access to Fairer Markets Are Needed to Support Small Forest Growers. Trees, Forests and People, 3(November 2020), 100052. https://doi.org/10.1016/j.tfp.2020.100052

Nurliza, Suharyani, A., \& Nugraha, A. (2021). The Product Features, Functions, and Benefits of Seafood Products for Competitive Repositioning. Agraris, 7(1), 1-110. https://doi.org/10.18196/agraris.v7i1.10571

Pambudi, S. H., Sunarto, N., \& Setyono, P. (2018). Agrotourism Development Strategy in Supporting Agriculture Development - Case Study Desa Wisata Kaligono (Dewi Kano) of Kaligesing District of Purworejo Regency. Analisis Kebijakan Pertanian, 16(2), 165. https://doi.org/10.21082/akp.v16n2.2018.165-184 
Pérez, D. G. R., Sendra, M. J. M., \& Gelats, F. L. (2020). Strategies and Drivers Determining The Incorporation of Young Farmers Into The Livestock Sector. Journal of Rural Studies, 78(June), 131-148. https://doi.org/10.1016/j.jrurstud.2020.06.028

Purwasih, R., Pranoto, Y. S., \& Atmaja, E. J. J. (2020). Muntok White Pepper Price Transmission in Bangka Belitung Island Province. AGRARIS: Journal of Agribusiness and Rural Development Research, 6(2). https://doi.org/10.18196/agr.6294

Rozaki, Z. (2020). COVID-19, Agriculture, and Food Security in Indonesia. Reviews in Agricultural Science, 8(October), 243-261. https://doi.org/10.7831/ras.8.0_243

Rozaki, Z., Wijaya, O., \& Wardana, C. K. (2021). Agriculture Developement Based on Regional Potency in Kulonprogro Regency. IOP Conference Series: Earth and Environmental Science, 683(1). https://doi.org/10.1088/1755-1315/683/1/012091

Saleh, K., \& Hubeis, A. V. S. (2018). Strengtheining Social Capital to Wards Self Reliance Of Rural Women Of Home Industry "Emping Melinjo" In Banten Province. Penyuluhan, 14(1), 43-51.

Satrianto, A., \& Sasongko, B. (2019). Determination of The Same Leading Sectors in Blitar City. Journal of Economic and Policy, 12(2), 382-402. https://doi.org/10.15294/jejak.v12i2.22616

Siswanto, S., Ardana, I. K., \& Karmawati, E. (2021). Opportunity for Increasing Productivity and Competitiveness of Pepper. Perspektif: Industrial Crops Research Review, 19(2), 149. https://doi.org/10.21082/psp.v19n2.2020.149-160

Sjafrizal. (2016). Perencanaan Pembangunan Daerah Dalam Era Otonomi (1st ed.). Jakarta: Rajawali Pers.

Sjafrizal. (2018). Analisis Ekonomi Regional dan Penerapannya di Indonesia (1st ed.). Depok: PT Raja Grafindo Persada.

Statistics of Kepulauan Bangka Belitung Province. (2020). Statistik Daerah Provinsi Kepulauan Bangka Belitung 2020. Pangkalpinang: Statistics of Kepualauan Bangka Belitung Province.

Statistics of Kepulauan Bangka Belitung Province. (2021). Kepulauan Bangka Belitung Province in Figure 2021. Pangkalpinang: Statistics of Kepualauan Bangka Belitung Province.

Susila, W. R., \& Setiawan, I. D. (2016). The Role of Estate Crop-Based Industries on Economic Growth and Equity: A Social Accounting Matrix Approach. Jurnal Agro Ekonomi, 25(2), 125. https://doi.org/10.21082/jae.v25n2.2007.125-147

Timisela, N. R., Masyhuri, M., \& Darwanto, D. H. (2021). Development Strategy of Sago Local Food Agroindustry Using Analytical Hierarchy Process Method. Agraris, 7(1), 36-52. https://doi.org/10.18196/agraris.v7i1.9378

Wang, Y., \& Wang, N. (2021). Exploring The Role of The Fisheries Sector in China's National Economy: An Input-Output Analysis. Fisheries Research, 243(April), 106055. https://doi.org/10.1016/j.fishres.2021.106055

Widodo, T. (2006). Perencanaan Pembangunan Teori dan Aplikasi. Yogyakarta: UPP STIM YKPN. 
Williams, C., Davies, W., Clark, R. E., Muench, A., \& Hyder, K. (2020). The Economic Contribution of Sea Angling from Charter Boats: A Case Study from The South $\begin{array}{llll}\text { Coast of } & \text { England. } & \end{array}$ https://doi.org/https://doi.org/10.1016/j.marpol.2020.104066

Williams, R. A., \& Kinard, J. C. (2003). A Strategy for Economic Development of The Forestry Sector in Tomsk, Russia. Journal of Forestry, 101(5), 36-41. https://doi.org/10.1093/jof/101.5.36

Yulianti, A. (2019). Potentials of Leading Sectors in Bangka Belitung Island Province on 2013-2017. Jurnal Ekonomi Pembangunan, 18(01), 39-50. 